\title{
PENGEMBANGAN PERANGKAT PEMBELAJARAN IPA BERBASIS INKUIRI TERBIMBING UNTUK MENUMBUHKAN MINAT DAN HASIL BELAJAR SISWA SMPN SATU ATAP
}

\author{
Eko Sulistyawan ${ }^{1)}$, . Endang Susantini ${ }^{2)}$, Sifak Indana ${ }^{3)}$ \\ ${ }^{1)}$ SMPN 4 Singosari Satu Atap Malang \\ ${ }^{2), 3)}$ Dosen Pascasarjana Prodi Pendidikan Sains Univesrtitas Negeri Surabaya \\ E-mail: sulistyawan_eko@yahoo.com
}

\begin{abstract}
This research aims to produce a quality guided inquiry-based learning materials to foster learning interest and learning outcomes to the student of SMPN Satu Atap. The quality was obtained by the description of validity, practicality and effectiveness of the learning material. This research is classified as development research, which develops the lesson plan, student's worksheets, student's textbook, assessment and questionnaires. The learning materials development use the design of 4D models. The trial of developed learning materials was done to the students of 7B SMPN 4 Singosari Satu Atap by using one group pretest posttest design. The validity of lesson plan, student's worksheets, student's textbook, assessment and questionnaires by two experts categorized as valid and feasible to be used with a little of revision. The implementation of lesson plans and guided inquiry learning phases categorized as good enough to phase I and II and good to phase II, IV and V. The effectiveness of application of guided inquiry-based learning materials have shown by increasing percentage of students learning interest from $44,55 \%$ to $84,20 \%$ and learning outcomes from $8 \%$ to $100 \%$.
\end{abstract}

\section{Keywords: Development of Learning Materials, Guided Inquiry, Learning Interest, Character of Environmental Cares}

\begin{abstract}
Abstrak: Penelitian ini bertujuan menghasilkan perangkat pembelajaran berbasis inkuiri terbimbing yang layak untuk menumbuhkan minat dan hasil belajar siswa SMPN Satu Atap. Kelayakan perangkat pembelajaran diperoleh dari deskripsi validitas, kepraktisan dan keefektifan perangkat pembelajaran.Penelitian ini tergolong penelitian pengembangan, yaitu mengembangkan perangkat pembelajaran yang terdiri dari Rencana Pelaksanaan Pembelajaran (RPP), Lembar Kegiatan Siswa (LKS), Buku Ajar Siswa (BAS), instrumen penilaian dan angket minat belajar siswa. Pengembangan perangkat mengikuti rancangan model 4-D. Perangkat pembelajaran yang telah dikembangkan diuji coba pada siswa kelas 7B SMPN 4 Singosari Satu Atap dengan menggunakan rancangan one group pretest posttest design.Hasil validasi perangkat pembelajaran oleh dua orang pakar menunjukkan bahwa RPP, LKS, BAS, instrumen penilaian dan angket minat belajar berkategori valid dan layak digunakan dengan sedikit revisi. Kepraktisan perangkat pembelajaran ditinjau dari keterlaksanaan RPP berkategori baik. Pembelajaran berbasis inkuiri terbimbing terlaksana cukup baik pada fase I dan II (merumuskan pertanyaan dan hipotesis), serta terlaksana dengan baik pada fase III, IV dan V (merancang \& melakukan percobaan, mengumpulkan \& menganalisis data dan menarik kesimpulan). Keefektifan perangkat pembelajaran dapat diketahui dari tumbuhnya minat belajar siswa dari $44,55 \%$ menjadi $84,20 \%$ serta peningkatan ketuntasan hasil belajar siswa dari $8 \%$ menjadi $100 \%$.
\end{abstract}

Kata kunci: Pengembangan Perangkat, Inkuiri Terbimbing, Minat Belajar, Karakter Peduli Lingkungan

\section{PENDAHULUAN}

SMPN 4 Singosari Satu Atap merupakan salah satu unit SMP Satu Atap yang berada di kecamatan Singosari kabupaten Malang. Tujuan pendirian SMP Satu Atap adalah untuk memperluas layanan pendidikan dasar serta mewujudkan program penuntasan wajib belajar 9 tahun pada daerah terpencil, terpencar dan terisolir (Pemprov Jatim, 2010). Sekolah ini berlokasi di dusun Blandit desa Wonorejo kecamatan Singosari, yang merupakan salah satu daerah rawan bencana banjir dan tanah longsor di kabupaten Malang - Jawa Timur.

Salah satu karakteristik SMPN 4 Singosari Satu
Atap adalah rendahnya minat belajar siswa. Menurut Profil SMPN 4 Singosari Satu Atap Tahun 2014, diperoleh informasi bahwa persentase rata-rata siswa putus sekolah (drop out) mencapai $10 \%$ pertahun. Tingginya persentase siswa putus sekolah ini juga mengakibatkan penurunan jumlah siswa yang mencapai $37 \%$ pada kurun waktu empat tahun terakhir.

Seiring dengan permasalahan di atas, pembelajaran IPA dengan metode yang tepat diharapkan dapat memberi kontribusi positif tidak hanya pada peningkatan hasil belajar IPA, tetapi juga minat belajar. Rutherford \& Ahlgren (dalam Zuchdi, dkk., 2013) menyatakan bahwa implementasi metode 
ilmiah dalam pembelajaran IPA selain berperan dalam pembentukan pola pikir logis, metode ilmiah juga dapat melatihkan nilai, sikap dan moral yang positif sebagai model dan pedoman dalam kehidupan. Menurut Kuhlthau, et al. (2007) model pembelajaran inkuiri terbimbing (guided inquiry) dapat meningkatkan minat dan motivasi belajar siswa. Holmes (2011) juga menyatakan bahwa pembelajaran inkuiri dapat mendorong aktivitas dan prestasi belajar siswa.

Beberapa hasil penelitian tentang penerapan model inkuiri terbimbing menunjukkan hasil yang positif terhadap hasil belajar IPA. Penelitian Jannah, dkk. (2012) menyimpulkan bahwa pembelajaran berbasis inkuiri terbimbing dapat meningkatkan pemahaman konsep IPA siswa SMP serta menumbuhkan karakter kerja sama, disiplin, mandiri, ingin tahu, kerja keras, jujur dan santun. Penelitian Hermawati (2012) juga menyimpulkan bahwa implementasi pembelajaran berbasis inkuiri mampu meningkatkan sikap ilmiah dan minat belajar siswa.

Berdasarkan latar belakang permasalahan di atas, maka peneliti akan melakukan penelitian pengembangan dengan judul "Pengembangan Perangkat Pembelajaran IPA Berbasis Inkuiri Terbimbing untuk Menumbuhkan Minat dan Hasil Belajar Siswa SMPN Satu Atap".

\section{METODE PENELITIAN}

Penelitian ini merupakan penelitian pengembangan (Research and Development), yaitu penelitian yang bertujuan untuk menghasilkan produk tertentu, dalam hal ini perangkat pembelajaran IPA berbasis inkuiri terbimbing. Pendekatan yang digunakan dalam penelitian ini adalah pendekatan deskriptif kualitatif.

Subjek dalam penelitian ini adalah perangkat pembelajaran IPA berbasis inkuiri terbimbing pada topik pencemaran lingkungan. Perangkat pembelajaran yang dikembangkan antara lain Rencana Pelaksanaan Pembelajaran (RPP), Lembar Kegiatan Siswa (LKS), Buku Ajar Siswa (BAS), instrumen penilaian serta instrumen angket minat belajar. Kelayakan perangkat pembelajaran didasarkan pada aspek validitas, kepraktisan dan keefektifan (Nieeven, 1999).

Pengambilan data penelitian dilaksanakan di kelas VIIB SMP Negeri 4 Singsosari Satu Atap pada semester genap tahun pelajaran 2014/2015 pada tanggal 30 Maret-4 April 2015.

Pengembangan perangkat pembelajaran pada penelitian ini mengadaptasi model 4-D dari Thiagarajan, et al. (1974). Proses pengembangan perangkat pembelajaran dengan model 4-D terdiri atas empat tahapan yaitu define (pendefinisian), design (perancangan), develop (pengembangan) dan disseminate (penyebaran). Pengembangan perangkat pada penelitian ini dibatasi hanya pada tahap ketiga yaitu develop (pengembangan). Pembatasan ini bertujuan untuk memaksimalkan fungsi pengembangan perangkat bagi guru yang menggunakan di sekolahnya sendiri atau mahasiswa untuk tujuan rujukan penelitian sehingga tahap disseminate (penyebaran) belum perlu dilakukan.

\section{A. Variabel Penelitian dan Teknik Pengumpulan Data}

1. Variabel Validitas Perangkat Pembelajaran

Deskripsi validitas perangkat ditinjau dari hasil validasi dua pakar pembelajaran. Tujuan validasi perangkat pembelajaran adalah untuk mendapatkan masukan, perbaikan perangkat dan menghasilkan perangkat pembelajaraan yang layak diujicobakan.

2. Variabel Kepraktisan Perangkat Pembelajaran

Kepraktisan perangkat didasarkan pada hasil pengamatan dua pengamat terhadap keterlaksanaan RPP dan sintaks inkuiri terbimbing selama proses pembelajaran. Observasi atau pengamatan dilakukan untuk mengumpulkan data penelitian yang berkenaan dengan sikap dan perilaku/kinerja. Keterlaksanaan RPP diukur melalui pengamatan yang dilakukan oleh dua orang guru bidang studi IPA di SMPN 4 Singosari Satu Atap Malang yang bertindak sebagai pengamat (observer) selama proses pembelajaran.

3. Variabel Keefektifan Perangkat Pembelajaran

Keefektifan perangkat ditinjau dari dua variabel yaitu minat belajar dan hasil belajar siswa.

Minat belajar siswa diukur dengan metode angket pada aspek assurance, relevance, interest, assesment dan satisfication (ARIAS). Pengisian angket dilaksanakan pada sebelum dan setelah pembelajaran dengan mengadaptasi model one group pretest posttest design (Tuckman, 1978).

Hasil belajar siswa diukur melalui tes hasil belajar yang dilaksanakan sebelum dan setelah proses pembelajaran (sebagai pretes dan postes).

\section{B. Instrumen Penelitian}

1. Lembar Validasi Perangkat Pembelajaran

Lembar validasi perangkat pembelajaran digunakan sebagai acuan penentuan predikat/kategori perangkat pembelajaran oleh validator. Lembar validasi disertai skor penilaian dan saran terhadap perangkat pembelajaran yang dikembangkan.

2. Lembar Pengamatan Kepraktisan Perangkat Pembelajaran

Lembar pengamatan kepraktisan perangkat pembelajaran dalam hal ini berupa lembar keterlaksanaan RPP dalam proses pembelajaran. Pengisian lembar pengamatan dilakukan dengan memberi tanda cek $(\sqrt{ })$ pada kolom yang sesuai dengan tahapan pembelajaran, serta memberi skor dari rentang 1-4 yang sesuai. Skala yang digunakan diadaptasi dari Borich (1994). 
Penilaian kualitas keterlaksanaan RPP ditentukan dengan menghitung rata-rata skor penilaian yang diberikan dua orang pengamat. Selain itu dilakukan perhitungan reliabilitas instrumen untuk menentukan baik tidaknya instrumen yang dikembangkan dengan rumus sebagai berikut:

Keterangan:

$$
\mathbf{R}=\left[\frac{A}{D+A}\right] \times 100 \%
$$

$$
\begin{aligned}
& \mathrm{R}=\text { Reliabilitas instrumen (percentage agreement) } \\
& \mathrm{A}=\text { Frekuensi kecocokan antar kedua penilai } \\
& \mathrm{D}=\text { frekuensi ketidakcocokan antar kedua penilai }
\end{aligned}
$$

Instrumen penilaian perangkat dikatakan reliabel jika nilainya $\geq 75 \%$ (Borich dalam Ibrahim 2005).

3. Lembar Keefektifan Penerapan Pembelajaran

a. Instrumen 03 (a): Lembar Angket Minat Belajar Siswa

Angket minat belajar siswa mengacu pada aspek ARIAS (assurance, relevance, interest, assesment dan satisfication) yang mengacu pada Ratumanan \& Laurens (2011)

b. Instrumen 03 (b): Lembar Soal Tes Hasil Belajar (THB)

Soal THB terdiri dari 10 soal pilihan ganda dan 5 soal isian dengan sebaran tingkat kognitif C1-C5. Soal THB digunakan sebagai soal pretes dan postes, mengacu pada Tuckman (1978).

\section{HASIL PENELITIAN DAN DISKUSI}

\section{A. Validitas Perangkat Pembelajaran}

Hasil validasi perangkat pembelajaran oleh dua orang pakar, yaitu Dosen Universitas Negeri Surabaya tertera pada Tabel 1 berikut:

Tabel 1. Hasil Validasi Perangkat Pembelajaran

\begin{tabular}{|c|c|c|c|c|}
\hline No & Jenis perangkat & Skor & $\mathrm{R}(\%)$ & Predikat \\
\hline 1 & $\begin{array}{c}\text { Rencana } \\
\text { Pelaksanaan } \\
\text { Pembelajaran }\end{array}$ & 3,67 & 96 & $\begin{array}{c}\text { Sangat } \\
\text { Baik }\end{array}$ \\
\hline 2 & $\begin{array}{c}\text { Lembar Kegiatan } \\
\text { Siswa }\end{array}$ & 3,67 & 90,48 & $\begin{array}{c}\text { Sangat } \\
\text { Baik }\end{array}$ \\
\hline 3 & Buku Ajar Siswa & 3,53 & 93,28 & Baik \\
\hline 4 & $\begin{array}{c}\text { Lembar Pengamatan } \\
\text { Sikap }\end{array}$ & 3,5 & 86 & Baik \\
\hline 5 & $\begin{array}{c}\text { Instrumen Tes Hasil } \\
\text { Belajar }\end{array}$ & 3,6 & 93,28 & $\begin{array}{c}\text { Sangat } \\
\text { Baik }\end{array}$ \\
\hline 6 & $\begin{array}{c}\text { Instrumen Tes } \\
\text { Kinerja } \\
\text { (Keterampilan) }\end{array}$ & 3,83 & 95,33 & $\begin{array}{c}\text { Sangat } \\
\text { Baik }\end{array}$ \\
\hline 7 & $\begin{array}{c}\text { Angket Minat } \\
\text { Belajar }\end{array}$ & 4 & 100 & $\begin{array}{c}\text { Sangat } \\
\text { Baik }\end{array}$ \\
\hline
\end{tabular}

\section{Keterangan:}

$\mathrm{R}$ : Reliabilitas
Berdasarkan Tabel 1 di atas dapat dimaknai bahwa perangkat pembelajaran yang terdiri dari RPP, LKS, BAS, lembar pengamatan karakter peduli lingkungan dan angket minat belajar dianggap baik dan layak untuk digunakan (Ratumanan \& Laurens, 2011). Menurut Borich (1994), reliabilitas di atas 75\% menunjukkan bahwa hasil penilaian di atas reliabel (terpercaya).

\section{B. Kepraktisan Perangkat Pembelajaran}

Kepraktisan perangkat pembelajaran ditinjau dari keterlaksanaan langkah-langkah pembelajaran berbasis inkuiri terbimbing yang diskenariokan dalam RPP seperti tertera pada Tabel 2 berikut:

Tabel 2. Keterlaksanaan Fase-fase Pembelajaran Berbasis Inkuiri Terbimbing

\begin{tabular}{|c|c|c|c|c|c|c|c|c|c|c|}
\hline Fase & \multicolumn{2}{|c|}{ TM-1 } & \multicolumn{2}{|c|}{ TM-2 } & \multicolumn{2}{|c|}{ TM-3 } & \multicolumn{2}{c|}{ TM-4 } & \multicolumn{2}{|c|}{ Rata2 } \\
\hline Inkuiri & $\mathrm{S}$ & $\mathrm{P}$ & $\mathrm{S}$ & $\mathrm{P}$ & $\mathrm{S}$ & $\mathrm{P}$ & $\mathrm{S}$ & $\mathrm{P}$ & $\mathrm{S}$ & $\mathrm{P}$ \\
\hline $\begin{array}{c}\text { Fase } \\
\text { I }\end{array}$ & 3 & $\mathrm{~B}$ & 3 & $\mathrm{~B}$ & 3 & $\mathrm{~B}$ & 3,5 & $\mathrm{~B}$ & 3,13 & $\mathrm{CB}$ \\
\hline $\begin{array}{c}\text { Fase } \\
\text { II }\end{array}$ & 3 & $\mathrm{~B}$ & 3 & $\mathrm{~B}$ & 3 & $\mathrm{~B}$ & 3,5 & $\mathrm{~B}$ & 3,13 & $\mathrm{CB}$ \\
\hline $\begin{array}{c}\text { Fase } \\
\text { III }\end{array}$ & 3,5 & $\mathrm{~B}$ & 3 & $\mathrm{~B}$ & 4 & $\mathrm{SB}$ & 4 & $\mathrm{SB}$ & 3,63 & $\mathrm{~B}$ \\
\hline $\begin{array}{c}\text { Fase } \\
\text { IV }\end{array}$ & 3,5 & $\mathrm{~B}$ & 3,5 & $\mathrm{~B}$ & 3,5 & $\mathrm{~B}$ & 4 & $\mathrm{SB}$ & 3,63 & $\mathrm{~B}$ \\
\hline $\begin{array}{c}\text { Fase } \\
\text { V }\end{array}$ & 3 & $\mathrm{~B}$ & 3,5 & $\mathrm{~B}$ & 3,5 & $\mathrm{~B}$ & 3,5 & $\mathrm{~B}$ & 3,38 & $\mathrm{CB}$ \\
\hline
\end{tabular}

Keterangan:

TM: Tatap Muka ke-

$$
\begin{aligned}
& S \text { : Skor B : Baik } \\
& \mathrm{P} \text { : Predikat SB : Sangat Baik }
\end{aligned}
$$

Fase I : Merumuskan masalah

Fase II : Merumuskan hipotesis

Fase III : Merancang \& melaksanakan penelitian

Fase IV : Mengumpulkan \& menganalisis data

Fase V : menarik kesimpulan \& generalisasi

Berdasarkan Tabel 2 di atas dapat dimaknai bahwa fase-fase pembelajaran berbasis inkuiri terbimbing dapat terlaksana dengan cukup baik. Berdasarkan rerata skor keterlaksanaan lima fase pembelajaran berbasis inkuiri terbimbing, ternyata fase I (merumuskan masalah) dan fase II (merumuskan hipotesis) menunjukkan skor paling rendah. Hal tersebut sesuai dengan hasil penelitian Gutwill \& Allen (2010) yang menyatakan bahwa langkah asking question (mengajukan pertanyaan) adalah langkah paling rumit dalam metode inkuiri dikarenakan langkah tersebut membutuhkan kemampuan meta-kognitif tinggi dan juga membutuhkan bantuan fasilitator. Menurut Rooijakkers (2010), proses merumuskan masalah mensyaratkan kemampuan penyadaran masalah dan analisis masalah. Ia menambahkan bahwa kemampuan mengajukan pertanyaan "mengapa" tergolong pertanyaan tingkat tinggi yang telah mencapai taraf bepikir abstrak. 
Keterlaksanaan fase III (merancang prosedur dan melakukan penelitian) serta fase IV (mengumpulkan dan menganalisis data) mencapai rerata skor tertinggi yaitu 3,63. Hal tersebut menunjukkan bahwa bimbingan yang diberikan peneliti berupa gambar, video pencemaran dan arahan verbal sangat membantu siswa dalam proses inkuiri. Menurut National Research Council (2000) pemberian bimbingan dalam sebuah pembelajaran berbasis inkuiri dapat diterima sepanjang pengalaman belajar yang terlangsung tetap berpusat pada siswa. Proporsi bimbingan guru inilah yang nantinya berpengaruh pada kategori sebuah pembelajaran dikatakan "inkuiri penuh" atau "inkuri sebagian".

\section{Keefektifan Perangkat Pembelajaran \\ 1. Deskripsi Minat Belajar Siswa}

Kriteria minat belajar siswa yang diukur pada penelitian ini mengadaptasi komponen minat model ARIAS yaitu terdiri dari aspek assurance (percaya diri), relevance (keterkaitan), interest (perhatian), assesment (penilaian) dan satisfication (kepuasan). Pembelajaran berbasis ARIAS merupakan sebuah model pembelajaran berbasis minat yang dimodifikasi dari pembelajaran berbasis motivasi ARCS (Attention, Relevance, Confidence dan Satisfaction) yang dikembangkan John M. Keller dengan menambahkan komponen Assessment (Rahman \& Amri, 2014). Hasil angket minat belajar siswa disajikan pada Tabel 3 dan 4 berikut:

Tabel 3. Hasil Angket Minat Belajar Sebelum Proses Pembelajaran Berbasis Inkuiri Terbimbing

\begin{tabular}{|l|c|c|c|c|c|c|c|c|c|c|}
\hline \multicolumn{1}{|c|}{ Aspek } & \multicolumn{4}{|c|}{ Favorable } & \multicolumn{4}{c|}{ Unfavorable } \\
\hline \multicolumn{1}{|c|}{ Minat } & 1 & 2 & 3 & 4 & 5 & 1 & 2 & 3 & 4 & 5 \\
\hline Assurance & 11 & 13 & 9 & 17 & 15 & 9 & 2 & 9 & 7 & 3 \\
\hline Relevance & 25 & 29 & 26 & 35 & 29 & 6 & 6 & 15 & 8 & \\
\hline Interest & 20 & 21 & 23 & 20 & 16 & 9 & 9 & 10 & 6 & 6 \\
\hline Assesment & 7 & 8 & 16 & 24 & 25 & 5 & 5 & 5 & 3 & 2 \\
\hline Satisfication & 27 & 34 & 41 & 35 & 28 & 4 & 4 & 8 & 2 & 2 \\
\hline
\end{tabular}

Tabel 4. Hasil Angket Minat Belajar Setelah Proses Pembelajaran Berbasis Inkuiri Terbimbing

\begin{tabular}{|l|c|c|c|c|c|c|c|c|c|c|}
\hline \multicolumn{1}{|c|}{ Aspek } & \multicolumn{5}{|c|}{ Favorable } & \multicolumn{4}{c|}{ Unfavorable } \\
\hline \multicolumn{1}{|c|}{ Minat } & 1 & 2 & 3 & 4 & 5 & 1 & 2 & 3 & 4 & 5 \\
\hline Assurance & 0 & 2 & 2 & 28 & 28 & 24 & 24 & 4 & 5 & 3 \\
\hline Relevance & 2 & 5 & 6 & 70 & 57 & 14 & 16 & 4 & 3 & 4 \\
\hline Interest & 7 & 8 & 11 & 38 & 36 & 19 & 23 & 6 & 7 & 5 \\
\hline Assesment & 1 & 2 & 6 & 35 & 36 & 8 & 7 & 2 & 3 & 0 \\
\hline Satisfication & 1 & 5 & 10 & 69 & 75 & 0 & 0 & 2 & 9 & 9 \\
\hline
\end{tabular}

Data Tabel 3 dan 4 di atas dideskripsikan dalam bentuk grafik yang tertera pada Gambar 1 sebagai berikut:

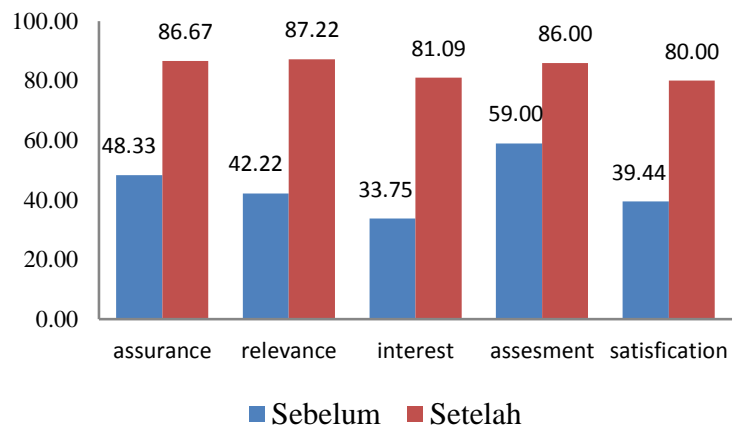

Gambar 1. Grafik Persentase Minat Belajar pada Aspek ARIAS

Berdasarkan Tabel 3 dan 4 serta Gambar 1 di atas dapat dinyatakan bahwa terdapat peningkatan minat belajar siswa setelah proses pembelajaran berbasis inkuiri terbimbing cukup tinggi. Persentase tumbuhnya minat belajar siswa pada aspek-aspek ARIAS antara lain: assurance (percaya diri) tumbuh $38,34 \%$ dari $48,33 \%$ menjadi $86,67 \%$; relevance (keterkaitan dengan kondisi diri) tumbuh $45 \%$ dari $42,22 \%$ menjadi $87,22 \%$; interest (menarik) tumbuh $47,34 \%$ dari $33,75 \%$ menjadi 81,09\%; assesment (objektivitas penilaian) tumbuh $27 \%$ dari $59,00 \%$ menjadi $86,00 \%$; dan satisfication (kepuasan) tumbuh $40,56 \%$ dari $39,44 \%$ menjadi $80,00 \%$. Secara rerata persentase tumbuhnya minat belajar siswa mencapai $39,65 \%$ dari $44,55 \%$ menjadi $84,20 \%$.

Tumbuhnya persentase minat belajar siswa di atas sebagai hasil dari pelaksanaan pembelajaran berbasis inkuiri terbimbing dapat dianalisis menggunakan perhitungan $N$-Gain Score yang tersaji pada Tabel 5 berikut:

Tabel 5. Perhitungan N-Gain Score minat belajar siswa

\begin{tabular}{|l|r|r|r|l|}
\hline $\begin{array}{l}\text { Aspek } \\
\text { Minat }\end{array}$ & Sebelum & Setelah & N-Gain & Ket \\
\hline Assurance & 48,33 & 86,67 & 0,74 & Tinggi \\
\hline Relevance & 42,22 & 87,22 & 0,78 & Tinggi \\
\hline Interest & 33,75 & 81,09 & 0,71 & Tinggi \\
\hline Assesment & 59,00 & 86,00 & 0,66 & Sedang \\
\hline Satisfication & 39,44 & 80,00 & 0,67 & Sedang \\
\hline Rerata & 44,55 & 84,20 & 0,71 & Tinggi \\
\hline
\end{tabular}

Berdasarkan Tabel 5 di atas dapat diketahui bahwa skor peningkatan (gain score) pada hasil angket minat belajar dikategorikan sebagai g-tinggi dengan ratarata gain sebesar 0,71 atau 71\%. Hal ini menunjukkan bahwa tumbuhnya minat belajar siswa benar-benar merupakan hasil dari pelaksanaan pembelajaran berbasis inkuiri terbimbing (Borich, 1994).

Hasil di atas sesuai dengan penelitian Holmes (2011) yang menyimpulkan bahwa pembelajaran inkuiri dapat meningkatkan minat (interest), 
pemahaman konsep dan prestasi (achievement) siswa. Hord, et al. (dalam NRC, 2000) juga berpendapat bahwa pembelajaran inkuiri jika dilakukan secara bertahap akan menimbulkan perubahan pola mengajar guru dan dapat memperbaiki persepsi serta minat belajar sains pada siswa.

\section{Deskripsi Hasil Belajar Siswa}

Hasil belajar pengetahuan beserta perhitungan $n$ gain (nilai pretes dan postes) tersaji pada Tabel 5 berikut:

Tabel 6. Hasil Pre-test Siswa

\begin{tabular}{|c|c|c|c|c|c|c|c|c|}
\hline \multirow{2}{*}{ No } & \multirow{2}{*}{ Kode Siswa } & \multicolumn{3}{|c|}{ Pretes } & \multicolumn{3}{|c|}{ Postes } & \multirow{2}{*}{-gain } \\
\cline { 2 - 8 } & & $\mathbf{S}$ & $\mathbf{K}$ & $\mathbf{P}$ & $\mathbf{S}$ & $\mathbf{K}$ & $\mathbf{P}$ & \\
\hline 1 & AG & 48 & 1,92 & C & 75 & 3,00 & B & 0,52 \\
\hline 2 & AN & 57 & 2,28 & C+ & 92 & 3,68 & A- & 0,81 \\
\hline 3 & AR & 46 & 1,84 & C & 92 & 3,68 & A- & 0,85 \\
\hline 4 & DA & 56 & 2,24 & C+ & 88 & 3,52 & A- & 0,73 \\
\hline 5 & DO & 58 & 2,32 & C+ & 84 & 3,36 & B+ & 0,62 \\
\hline 6 & DW & 46 & 1,84 & C & 84 & 3,36 & B+ & 0,70 \\
\hline 7 & FA & 52 & 2,08 & C & 88 & 3,52 & A- & 0,75 \\
\hline 8 & FT & 59 & 2,36 & C+ & 90 & 3,60 & A- & 0,76 \\
\hline 9 & HA & 58 & 2,32 & C+ & 88 & 3,52 & A- & 0,71 \\
\hline 10 & NA & 51 & 2,04 & C & 80 & 3,20 & B+ & 0,59 \\
\hline 11 & N0 & 53 & 2,12 & C & 86 & 3,44 & B+ & 0,70 \\
\hline 12 & SU & 54 & 2,16 & C & 92 & 3,68 & A- & 0,83 \\
\hline 13 & SY & 53 & 2,12 & C & 86 & 3,44 & B+ & 0,70 \\
\hline 14 & TA & 39 & 1,56 & C- & 85 & 3,40 & B+ & 0,75 \\
\hline 15 & DE & 45 & 1,80 & C & 78 & 3,12 & B & 0,60 \\
\hline 16 & HU & 56 & 2,24 & C+ & 85 & 3,40 & B+ & 0,66 \\
\hline 17 & AS & 46 & 1,84 & C & 78 & 3,12 & B & 0,59 \\
\hline 18 & ND & 60 & 2,40 & C+ & 92 & 3,68 & A- & 0,80 \\
\hline 19 & PI & 67 & 2,68 & B- & 90 & 3,60 & A- & 0,70 \\
\hline 20 & IN & 70 & 2,80 & B- & 92 & 3,68 & A- & 0,73 \\
\hline 21 & KI & 48 & 1,92 & C & 75 & 3,00 & B & 0,52 \\
\hline 22 & KA & 57 & 2,28 & C+ & 92 & 3,68 & A- & 0,81 \\
\hline 23 & HU & 58 & 2,32 & C+ & 92 & 3,68 & A- & 0,81 \\
\hline 24 & LA & 45 & 1,80 & C & 78 & 3,12 & B & 0,60 \\
\hline 25 & BA & 54 & 2,16 & C & 88 & 3,52 & A- & 0,74 \\
\hline & Rerata & $\mathbf{5 3 , 4 4}$ & $\mathbf{2 , 1 4}$ & C & $\mathbf{8 6 , 2 5}$ & $\mathbf{3 , 4 5}$ & B+ & $\mathbf{0 , 7 1}$ \\
\hline
\end{tabular}

Keterangan:

$$
\begin{aligned}
& \mathrm{S}: \text { Skor } \\
& \mathrm{K}: \text { Konversi } \\
& \mathrm{P}: \text { Predikat Nilai }
\end{aligned}
$$

Berdasarkan Tabel 5 di atas diperoleh informasi bahwa rata-rata nilai pretes yang dicapai siswa adalah 2,14 (C). Sebanyak 23 siswa mendapat nilai di bawah KKM (kriteria ketuntasan minimal) yaitu 2,67 (B-) dan hanya 2 orang siswa yang berhasil mencapai nilai pretes di atas KKM. Hal ini menunjukkan bahwa $92 \%$ siswa tidak tuntas dalam aspek pengetahuan berdasarkan hasil nilai pretes. Berdasarkan nilai postes yang dicapai diketahui bahwa seluruh siswa (100\%)

telah melampaui KKM, yaitu dengan rata-rata nilai 3,45 $(\mathrm{B}+)$.

Perhitungan rerata $n$-gain mencapai skor 0,71 atau 71\%. Menurut Borich (1994) skor n-gain tersebut tergolong dalam predikat tinggi. Hal ini berarti bahwa penerapan perangkat pembelajaran berbasis inkuiri terbimbing dalam proses belajar mengajar dapat memperbaiki hasil belajar pengetahuan siswa.

Hasil pretes dan postes aspek pengetahuan juga dapat menjelaskan pemahaman siswa terhadap topik pencemaran lingkungan sebelum dan setelah dibelajarkan menggunakan perangkat pembelajaran 
berbasis inkuiri terbimbing yang telah dikembangkan. Deskripsi pemahaman siswa terhadap topik pencemaran lingkungan tersaji pada Gambar 2 berikut:

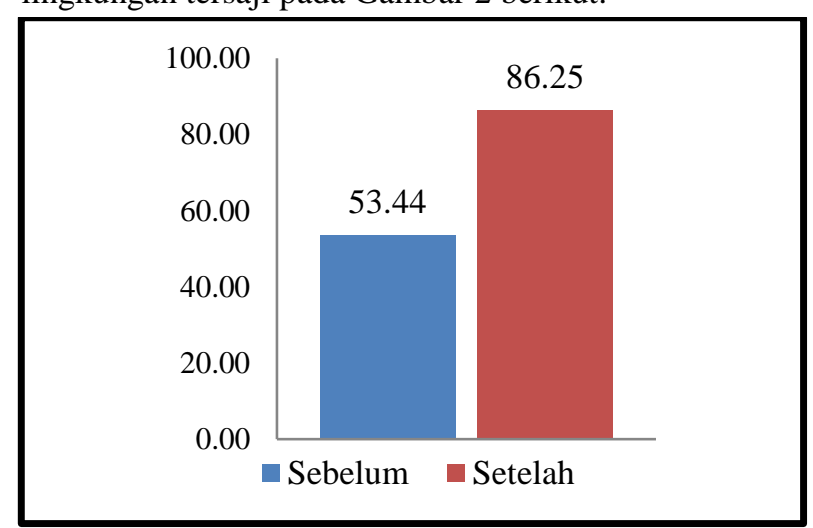

Gambar 2. Persentase pemahaman siswa terhadap topik pencemaran lingkungan sebelum dan setelah pembelajaran berbasis inkuiri terbimbing

Berdasarkan Gambar 3 di atas dapat diketahui bahwa sebelum pembelajaran berbasis inkuiri terbimbing dilakukan, siswa telah mampu menguasai topik pencemaran lingkungan sebesar $53,44 \%$. Hal ini membuktikan bahwa topik pencemaran lingkungan benar-benar relevan dengan kondisi riil siswa sehingga menyebabkan mereka telah cukup paham tentang topik pencemaran lingkungan meskipun belum dijelaskan.

Proses pembelajaran berbasis inkuiri terbimbing yang dilakukan mampu meningkatkan pemahaman mereka terhadap topik yang sama sehingga setelah pembelajaran berlangsung persentase pemahaman siswa mencapai $86,25 \%$. Peningkatan persentase pemahaman siswa akan menyebabkan pengetahuan yang dimiliki lebih bermakna (Irwandi, 2009). Hasil tersebut menguatkan hasil penelitian sebelumnya yang menyatakan bahwa pembelajaran IPA berbasis inkuiri terbimbing dapat meningkatkan hasil belajar siswa (Jannah, dkk., 2012; Dewi, dkk., 2013; Yuniastuti, 2013; Jaya, dkk., 2014).

\section{Temuan Penelitian}

1. Perangkat pembelajaran yang dikembangkan terbukti valid berdasarkan hasil validasi pakar dan praktis diterapkan dalam proses pembelajaran.

2. Keterlaksanaan fase-fase pembelajaran inkuiri terbimbing yang diskenariokan dalam RPP memperoleh skor keterlaksanaan pada rentang 3,133,65 sehingga dapat disimpulkan bahwa perangkat pembelajaran yang dikembangkan terbukti praktis untuk dilaksanakan.

3. Penerapan perangkat pembelajaran yang dikembangkan juga terbukti efektif menumbuhkan minat belajar dari $44,55 \%$ menjadi $84,20 \%$ serta ketuntasan hasil belajar pengetahuan dari $8 \%$ (pretes) menjadi 100\% (postes).

\section{KESIMPULAN}

\section{A. Simpulan}

Berdasarkan hasil validitas, kepraktisan dan keefektifannya, perangkat pembelajaran berbasis inkuiri terbimbing yang dikembangkan terbukti layak digunakan dalam proses pembelajaran.

\section{B. Saran}

1. Penerapan pembelajaran berbasis inkuiri terbimbing pada siswa SMPN Satu Atap yang memiliki keterampilan bertanya (asking question) rendah membutuhkan bobot bimbingan yang lebih banyak, khususnya pada fase I dan II (merumuskan masalah dan hipotesis).

2. Perlu dilakukan pembelajaran remedial berkaitan dengan topik "Metode Ilmiah" sehingga dapat meningkatkan kesiapan siswa dalam belajar IPA dengan metode inkuiri dan sejenisnya.

\section{REFERENSI}

Borich, G., D. (1994). Observation Skills for Effective Teaching, New York: Mc. Millan Publishing Company

Dewi, K. Sadia, I. W. Ristiati, N.P (2013) Pengembangan Perangkat Pembelajaran IPA Terpadu dengan Setting Inkuiri Terbimbing untuk Meningkatkan Pemahaman Konsep dan Kinerja Ilmiah Siswa. e-Journal Program Pasca-sarjana Universitas Pendidikan Ganesha. Vol. 3.

Gutwill, J. P., \& Allen, S. (2010). Facilitating Family Group Inquiry at Science Museum Exhibits. Science Education Journal. Vol. IV. No. 94.

Hermawati, Ni Wayan, M. (2012) Pengaruh Model Pembelajaran Inkuiri Terhadap Penguasaan Konsep Biologi dan Sikap Ilmiah Siswa SMA Ditinjau dari Minat Belajar Siswa. e-Journal Program Pascasarjana Universitas Pendidikan Ganesha Program Studi IPA. Vol. 1.

Holmes, V.L. (2011). "Standardizing the Inquiry Lesson: Improving the Caliber of Science Inquiry". Electronic Journal of Literacy Through Science. Vol.10.

Irwandi. (2009). Pengaruh Pendekatan Kontekstual Melalui Strategi Inkuiri dan Masyarakat Belajar terhadap Hasil Belajar Kognitif."Jurnal Pendidikan Biologi”. Vol. 1. No.1.

Jannah, M. Sugianto dan Sarwi (2012). "Pengembangan Perangkat Pembelajaran Berorientasi Nilai Karakter Melalui Inkuiri Terbimbing Materi Cahaya pada Siswa Kelas VIII Sekolah Menengah Pertama". Journal of Innovative Science Education. Vol. 1 No. 1.

Jaya, M. Sadia, I.W. dan Arnyana, I.B. (2014). Pengembangan Perangkat Pembelajaran Biologi 
Bermuatan Pendidikan Karakter dengan Setting Guided Inquiry untuk Meningkatkan Karakter dan Hasil Belajar Siswa SMP. e-Journal Program Pascasarjana Universitas Pendidikan Ganesha Program Studi IPA. Vol. 4.

Kuhlthau, C.C., Maniotes, L.K., Caspari, A.K. (2007). Guided Inquiry, Learning in the $21^{\text {st }}$ Century. London: Libraries Unlimited

National Reseach Council. (2000). Inkuiri dan Standarstandar Pendidikan Sains Nasional. Alih bahasa oleh: Ismunandar. Agustiani, E.D. dan Astuti, F.R. Washington D.C: National Academy Press.

Nieeven, N. (1999). "Prototyping to Reach Product Quality”. In Jan Van Den Akker, R. M. Branch, K. Gustafson, N. Nieeven \& Tjeerd Plomp (Eds). Design Approaches and Tools in Education and Training. Dorgrecht: Kluwer Academic Publisher.

Pemprov Jatim. (2010). Panduan Acara Peresmian SDSMP Satu Atap Provinsi Jawa Timur di Lumajang, 21 Maret 2010. Surabaya: Pemprov Jatim.

Rahman, M. dan Amri, S. 2014. Model Pembelajaran ARIAS Terintegratif. Bandung. Penerbit Prestasi Putra Karya
Ratumanan, T. G., dan Laurens, T. (2011). Penilaian Hasil Belajar pada Tingkat Satuan Pendidikan.Edisi 2. Surabaya: Unesa University Press.

Rooijakkers, A. (2010). Mengajar dengan Sukses. Jakarta: Grasindo

Thiagarajan, S. Dorothy, S. Semmel, and Melvyn I. Semmel. (1974). Instructional Development for Training Teachers of Exceptional Children. Source Book. Bloomington: Center for Innovation on Teaching The Handicapped.

Tuckman, Bruce. W. (1978). Conducting Educational Research. Second Edition. San Diego: Harcourt Brace Jovanovich Publishers.

Yuniastuti, E. (2013). Peningkatan Ketrampilan Proses, Motivasi dan Hasil Belajar Biologi dengan Strategi Pembelajaran Inkuiri Terbimbing pada Siswa Kelas VII SMP Kartika V-1 Balikpapan. “Jurnal Penelitian Pendidikan”. Vol. 14 No. 1.

Zuchdi, D., Prasetya Z. K., dan Masruri, M. S. (2013). Model Pendidikan Karakter Terintegrasi dalam Pembelajaran dan Pengembangan Kultur Sekolah. Yogyakarta: Multi Persada. 